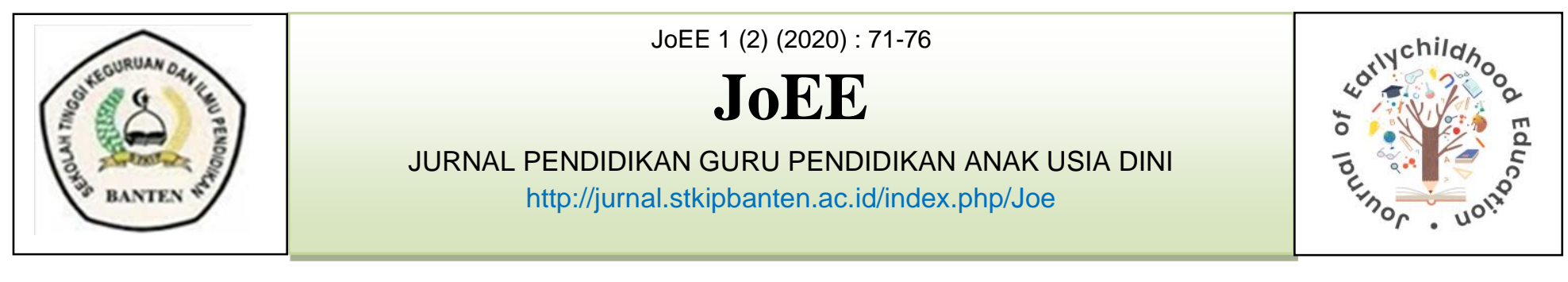

\title{
MENINGKATKAN KEMAMPUAN MOTORIK HALUS ANAK USIA DINI MELALUI KEGIATAN MEWARNAI DI KELOMPOK B PAUD TUNAS MAWAR KECAMATAN PETIR
}

\author{
Heni Herlina \\ Heniherlina.s.s.mpd@gmail.com \\ Pendidikan Guru Pendidikan Anak Usia Dini \\ Sekolah Tinggi Keguruan dan Ilmu Pendidikan Banten
}

\begin{abstract}
ABSTRAK
Kegiatan coret mencoret ini adalah bagian dari perkembangan motorik anak, sehingga dengan dorongan guru dan kesempatan yang diberikan, anak akan termotivasi membuat gambar. Salah satu kegiatan fisik motorik bagi anak khususnya motorik halus yaitu mewarnai. Mewarnai merupakan salah satu kegiatan yang dapat merangsang dan meningkatkan kemampuan motorik halus anak usia dini. Tujuan penelitian dalam skripsi ini ialah untuk mengetahui dan memperoleh data serta informasi tentang peningkatan kemampuan motorik halus anak usia dini melalui kegiatan mewarnai di kelompok B PAUD Tunas Mawar Kecamatan Petir. Model penelitian tindakan kelas yang digunakan adalah model Kemmis dan Mc. Taggart. Jumlah siklus penelitian yang akan digunakan sebanyak 2 siklus dengan masingmasing siklus terdiri dari 2 kali pertemuan. Teknik pengumpulan data yang digunakan dalam penelitian ini adalah observasi pada guru dan pada murid dalam catatan anekdot serta dokumentasi berupa foto, video dan LKA. Pada penelitian ini digunakan teknik analisis deskriptif kualitatif, yaitu suatu metode penilaian yang bersifat menggambarkan kenyataan atau fakta sesuai dengan data yang diperoleh. Pengecekan teman sejawat merupakan teknik pengujiian keabsahan data melalui cara mengekspos hasil penelitian kepada teman sejawat dalam bentuk diskusi untuk menghasilkan pemahaman yang lebih luas, komprehensif, dan menyeluruh. Hasil penelitian dan pembahasan membuktikan bahwa terdapat persentase keberhasilannya hanya sebesar 73\% pada siklus 1 naik pada siklus 2 menjadi sebesar $100 \%$ dengan 3 orang anak yang mendapat nilai BSH (Berkembang Sesuai Harapan) dan 12 orang anak mendapat nilai BSB (Berkembang Sangat Baik). Adapun tindakan guru pada siklus ini dengan mengajarkan cara mewarnai menggunakan pensil warna mendapatkan nilai 100 sehingga kemampuan motorik halus anak pada siklus ini pada perkembangan sangat meningkat dan meningkat. Persentase peningkatan perkembangan motorik halus tersebut didukung oleh tindakan guru pada siklus 2 yang mengajarkan cara mewarnai menggunakan pensil warna mendapatkan nilai 100 sehingga kemampuan motorik halus anak pada siklus ini pada perkembangan sangat meningkat dan meningkat.
\end{abstract}

Kata Kunci :Perkembangan, Motorik Halus, Mewarnai, Anak Usia Dini. 


\section{PENDAHULUAN}

\section{A. Latar Belakang}

Kegiatan menggambar untuk anak usia dini biasanya diawali dengan berbagai coretan. Kegiatan coret mencoret ini adalah bagian dari perkembangan motorik anak, sehingga dengan dorongan guru dan kesempatan yang diberikan, anak akan termotivasi membuat gambar. Salah satu kegiatan fisik motorik bagi anak khususnya motorik halus yaitu mewarnai.

Latar belakang penelitian ini dilakukan karena adanya permasalahan yang dialami oleh anak-anak di kelompok B PAUD Tunas Mawar Kecamatan Petir. Masalah yang ditemukan berdasarkan pengamatan awal ialah di antaranya anak memiliki kekurangan dalam hal mewarnai. Artinya anak mewarni gambar kurang rapi yaitu masih keluar dari garis. Selain itu tulisan anak dalam menulis dasar masih belum rapi. Ini merupakan permasalahan yang serius bagi anak usia dini.

Hal tersebut dikarenakan kemampuan motorik halus anak belum sempurna, sehingga perlu dirangsang agar kemampuan motorik halusnya semakin baik dan berkembang. Mewarnai merupakan salah satu kegiatan yang dapat merangsang dan meningkatkan kemampuan motorik halus anak usia dini.

Permasalahan ini penting untuk diteliti karena anak usia 5-6 tahun atau yang berada di kelompok B selanjutnya akan memasuki dunia sekolah dasar. Sehingga kegiatan belajar di kelompok B ini harus meliputi kegiatan yang berkaitan dengan perangsangan motorik halusnya agar kelak anak dapat menulis dengan rapih dan baik

B. Rumusan Masalah

Dari latar belakang yang telah diuraikan sebelumnya, maka dapat dirumuskan masalah dalam penelitian ini yaitu apakah kegiatan mewarnai dapat meningkatan kemampuan motorik halus anak usia dini di kelompok B PAUD Tunas Mawar Kecamatan Petir?

C. Tujuan Penelitian

Tujuan penelitian dalam skripsi ini ialah untuk mengetahui dan memperoleh data serta informasi tentang peningkatan kemampuan motorik halus anak usia dini melalui kegiatan mewarnai di kelompok B PAUD Tunas Mawar Kecamatan Petir.

\section{LANDASAN TEORI}

Menurut Susanto motorik halus mencakup kemampuan dan kelenturan menggunakan jari dan alat untuk mengeksplorasi dan mengekspresikan diri dalam berbagai bentuk (2017 : 174). Menurut Papalia dan Olds dalam Suyadi dan Ulfah berpandangan perkembangan anak usia dini dapat dikategorikan yaitu kategori perkembangan fisik dan intelektual yang di dalamnya memuat ketarampilan motorik serta kategoti perkembangan kepribadian dan sosial (2015 : 58-59).

Menurut Latif dan kawan-kawan perkembangan fisik anak di antaranya kesadaran penuh pada tubuh, perkembangan pada motorik kasar, dan perkembangan motorik halus (2016 :64). Menurut Mursid 
pada usia 5-6 tahun koordinasi gerakan motorik halus berkembang pesat. Pada masa ini anak telah mampu mengoordinasikan gerasakan visual motorik, seperti mengoordinasikan gerakan mata dengan tangan, lengan dan tubuh secara bersamaan, antara lain dapat dilihat pada waktu anak menulis atau menggambar (2015 : 12).

Menurut Susanto kemampuan yang berhubungan dengan keterampilan tangan dapat dapat dikembangkan dengan permainanpermainan yaitu finger painting dengan tepung kanji, menjiplak huruf-huruf geometri, melukis dengan cat air, mewarnai dengan sederhana, menjahit dengan sederhana, merobek kertas koran, menciptakan bentuk-bentuk dengan balok, mewarnai gambar dan lainlain (2011: 62).

Menurut Marisson anak prasekolah juga senang berpartisipasi dalam aktivitas gerak ringan seperti menggambar, mewarnai, melukis, memotong, dan menempel (2012 : 221). Menurut Sururiah menggambar dan

mewarnai menjadi aktivitas yang ideal bagi anak untuk mengekspresikan diri (2013: 212). Menurut Olivia mewarnai membuat anak konsentrasi, dan mengungkap emosi (2013 : 23).

Menurut Rasmitadila kegiatan yang dapat dilakukan untuk mengembangkan motorik halus anak usia dini dengan mewarnai gambar. Alat dan bahan yang digunakan adalah crayon, tujuan kegiatan adalah melatih motorik halus anak dan mengenal warna (2014: 10). Menurut Umama alat lukis yang bisa digunakan adalah jenis crayon, pewarna makanan dan kuas, dan mewarnai dengan playdough (2016 : 104-106)

Menurut Mulyani penting untuk diketahui adalah dalam mewarnai gambar pun anak tidak boleh diarahkan. Misalnya dalam mewarnai gunung dengan warna biru, mewarnai matahari dengan warna kuning, atau yang lainnya. Hal ini dilakukan untuk melatih imajinasi anak. Anak bebas menggunakan warna apa saja menurut keinginan anak (2017 : 67).

\section{METODE PENELITIAN}

\section{A. Metode Penelitian}

Metodologi penelitian yang digunakan adalah Penelitian Tindakan Kelas, karena di kelas atau kelompok B PAUD Tunas Mawar terdapat masalah sehingga Penelitian Tindakan Kelas dianggap tepat dalam memecahkan masalah. Penelitian tindakan kelas memiliki model, adapun model penelitian tindakan kelas yang digunakan adalah model Kemmis dan Mc. Taggart. Jumlah siklus penelitian yang akan digunakan sebanyak 2 siklus dengan masing-masing siklus terdiri dari 2 kali pertemuan.

\section{B. Subjek dan Lokasi Penelitian}

Subjek penelitian merupakan sasaran untuk mendapatkan suatu data. Pada penelitian yang dilakukan akan menjadikan subjek penelitiannya ialah siswa kelompok B yang berjumlah 15 orang anak. Lokasi penelitian atau tempat penelitian tersebut berlangsung dilakukan di PAUD Tunas Mawar Kecamatan Petir.

C. Teknik Pengumpulan Data 
Teknik pengumpulan data merupakan cara untuk memperoleh data dalam kegiatan penelitian yang memenuhi standar yang ditetapkan. Teknik pengumpulan data yang digunakan dalam penelitian ini adalah dokumentasi dan observasi.

\section{Teknik Analisis Data}

Pada penelitian ini digunakan teknik analisis deskriptif kualitatif, yaitu suatu metode penilaian yang bersifat menggambarkan kenyataan atau fakta sesuai dengan data yang diperoleh. Suatu penelitian dapat dikatakan berhasil apabila kemampuan anak setalah dilakukan tindakan menjadi lebih baik dari sebelumnya. Adapun untuk memperoleh gambaran tentang proses pembelajaran di kelas menggunakan catatan anekdot.

Penelitian tindakan kelas ini dikatakan berhasil apabila indikator keberhasilan penelitian telah mencapai minimal atau lebih dari 90\% anak dari jumlah keseluruhan mencapai keberhasilan belajar di BSH (Berkembang Sesuai Harapan) atau BSB (Berkembang Sangat Baik). Adapun jika pada siklus ke II tidak mengalami peningkatan perkembangan maka akan dilakukan penelitian pada siklus selanjutnya. Jika pada siklus ke II telah mengalami peningkatan perkembangan lebih dari $90 \%$, maka penelitian dihentikan.

F. Teknik Pengecekan Keabsahan Data

Pengecekan teman sejawat merupakan teknik pengujiian keabsahan data melalui cara mengekspos hasil penelitian kepada teman sejawat dalam bentuk diskusi untuk menghasilkan pemahaman yang lebih luas, komprehensif, dan menyeluruh. Hal ini dilakukan agar peneliti tetap memertahankan sikap terbuka dan jujur atas temuan, dapat menguji hipotesis kerja yang telah dirumuskan, menggunakannya sebagai alat pemgembangan langkah penelitian selanjutnya serta sebagai pembanding.

\section{HASIL DAN PEMBAHASAN}

A. Deskripsi Tempat dan Objek Penelitian

Nama PAUD Tunas Mawar, No Statistik PAUD 98282830, alamat PAUD Kp. Sabrang, Otonomi Daerah Petir Kecamatan Petir, Kabupaten/Kota Petir, Provinsi Banten.

B. Hasil dan Pembahasan

Hasil tindakan pada penelitian siklus 1 pertemuan 1 dan 2 persentase keberhasilannya hanya sebesar $73 \%$ dengan 11 orang anak yang mendapat nilai $\mathrm{BSH}$ (Berkembang Sesuai Harapan). Adapun tindakan guru pada siklus ini dengan mengajarkan cara mewarnai menggunakan crayon mendapatkan nilai 50 dan 75 sehingga kemampuan motorik halus anak pada siklus ini pada perkembangan meningkat saja.

\section{Diagram 4.1 Peningkatan Nilai LKA}

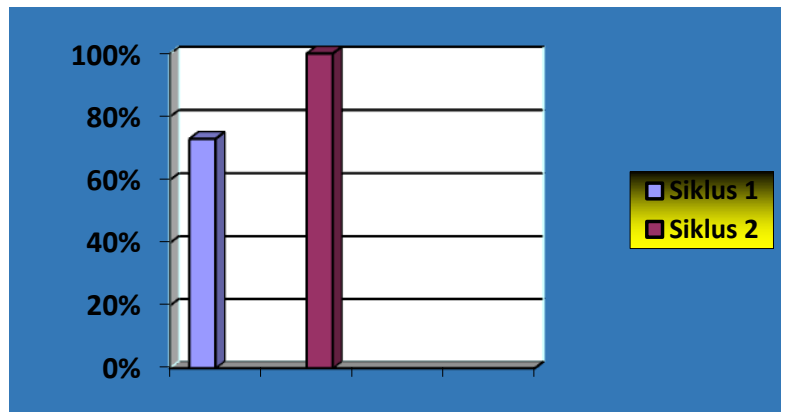


Hasil tindakan pada penelitian siklus 2 pertemuan 1 dan 2 persentase keberhasilannya hanya sebesar 100\% dengan 3 orang anak yang mendapat nilai BSH (Berkembang Sesuai Harapan) dan 12 orang anak mendapat nilai BSB (Berkembang Sangat Baik). Adapun tindakan guru pada siklus ini dengan mengajarkan cara mewarnai menggunakan pensil warna mendapatkan nilai 100 sehingga kemampuan motorik halus anak pada siklus ini pada perkembangan sangat meningkat dan meningkat

Diagram 4.2 Persentase Peningkatan Motorik Halus Anak

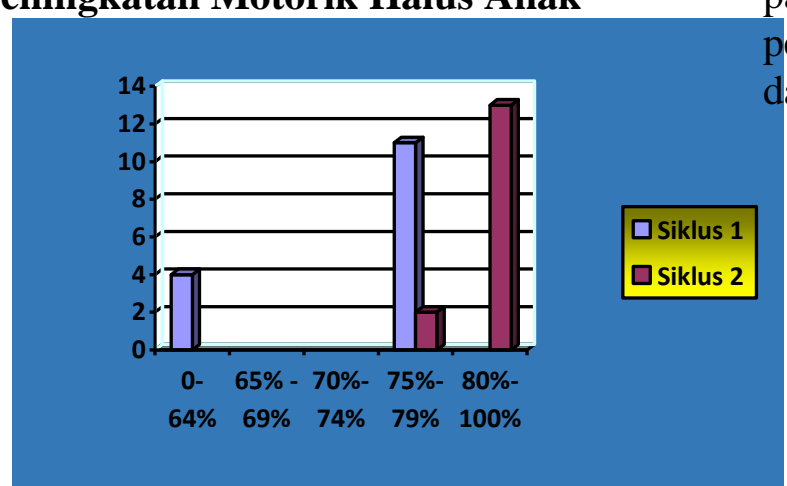

Peningkatan nilai LKA anak mendukung perkembangan motorik halus anak pada siklus 2 memperoleh peningkatan dengan persentase $80 \%$ - $100 \%$ Sangat Meningkat sebanyak 12 orang anak. Persentase $75 \%$ - $79 \%$ Meningkat sebanyak 3 orang anak, persentase $70 \%-74 \% \quad$ Cukup Meningkat dan 65\% - 69\%

Kurang Meningkat tidak diperoleh oleh anak.

Persentase peningkatan perkembangan motorik halus tersebut didukung oleh tindakan guru pada siklus 2 yang mengajarkan cara mewarnai menggunakan pensil warna mendapatkan nilai 100 sehingga kemampuan motorik halus anak pada siklus ini pada perkembangan sangat meningkat dan meningkat.

Diagram 4.2 Nilai Kemampuan

Peningkatan motorik halus anak usia dini terlihat dari hasil penilaian LKA yang menunjukkan bahwa persentase keberhasilan pada siklus 1 sebesar $73 \%$ dengan 11 orang anak yang mendapat nilai BSH (Berkembang Sesuai Harapan) naik pada siklus 2 menjadi $100 \%$ dengan 3 orang anak yang mendapat nilai BSH (Berkembang Sesuai Harapan) dan 12 orang anak mendapat nilai BSB (Berkembang Sangat Baik).

\section{Guru}

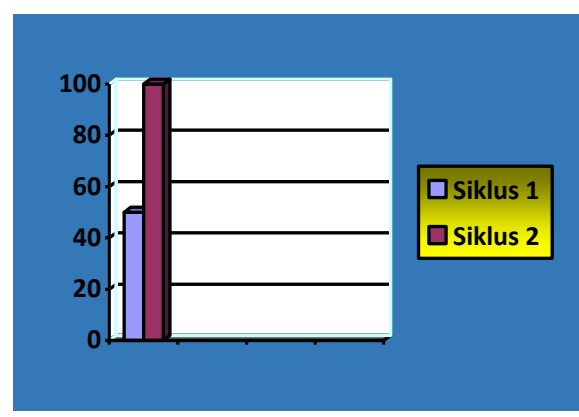


Berdasarkan rumusan masalah apakah terdapat peningkatan kegiatan mewarnai dapat meningkatan kemampuan motorik halus anak usia dini di kelompok B PAUD Tunas Mawar Kecamatan Petir, sehingga hasil penelitian membuktikan bahwa terdapat persentase keberhasilannya hanya sebesar $73 \%$ pada siklus 1 naik pada siklus 2 menjadi sebesar $100 \%$ dengan 3 orang anak yang mendapat nilai BSH (Berkembang Sesuai Harapan) dan 12 orang anak mendapat nilai BSB (Berkembang Sangat Baik).

Persentase peningkatan perkembangan motorik halus tersebut didukung oleh tindakan guru pada siklus 2 yang mengajarkan cara mewarnai menggunakan pensil warna mendapatkan nilai 100 sehingga kemampuan motorik halus anak pada siklus ini pada perkembangan sangat meningkat dan meningkat.

\section{DAFTAR PUSTAKA}

AR, Syamsudn dan Vismaia S. Damaianti. (2011). Metode Penelitian Pendidikan Bahasa. Bandung : Remaja. Rosdakarya

Desmita. (2015). Psikologi Perkembangan. Bandung : Rosdakarya Remaja.

Dimyati, Jhoni. (2013). Metodologi Penelitian Pendidikan dan Aplikasinya Pada PAUD. Jakarta : Prenadamedia Group.

Latif, Muhtar dkk. (2016). Orientasi Baru Pendidikan Anak Usia Dini : Teori dan Aplikasi. Jakarta : Kencana.

Morrison, S George. (2012). Buku Dasardasar Pendidikan Anak
Usia Dini. Penerjemah: Suci

Romadhona dan Apri Widiastuti. Jakarta : PT Indeks. Mulyani, Novi. (2017) Pengembangan Seni Anak Usia Dini. Bandung : PT. Remaja RosdaKarya.

Mursid. (2015). Belajar dan Pembelajaran PAUD. Bandung : PT. Remaja RosdaKarya.

Olivia, Femi (2013). Gembira Bermain Corat-Coret : Coretan Warna-Warni Untuk Menstimulasi Otak Anak Sejak Dini. Jakarta : Gramedia.

Rasmitadila. (2014). Buku Aktivitas Anak : Melatih Motorik Halus Usia 3-6 Tahun. Jakarta : Media Pusindo.

Suririnah. (2013). Buku Pintar Mengasuh Batita. Jakarta : Gramedia.

Susanto, Ahmad. (2011). Perkembangan Anak Usia Dini - Pengantar dalam Berbagai Aspeknya. Jakarta

Prenadamedia Group.

—. (2017). Pendidikan Anak Usia Dini : Konsep dan Teori. Jakarta : Bumi Aksara.

Suyadi, dan Maulidya Ulfah. (2016).

Konsep Dasar PAUD.

Bandung: PT. Remaja Rosdakarya.

Umama. (2016). Pojok Bermain Anak. Yogyakarta 